\title{
THE APPLICATION OF NATURAL DYES TO BATIK USING MANGROVE SPESIES RHIZOPORA STYLOSA, SOGA TINGI (CERIOPSTAGAL) AND INDIGOFERA
}

\author{
Paryanto*, Sunu Herwi Pranolo, and Ari Diana Susanti \\ Chemical Engineering, Engineering Faculty, Sebelas Maret University, \\ Jl. Ir. Sutami No.36 A, Jebres, Surakarta, 57126 \\ *e-mail: Paryanto.uns@gmail.com
}

\begin{abstract}
Technological advance leads the natural dyes to be eroded by the synthetic one. Synthetic colorant has advantages of salient, more uniform color and more practical use. Meanwhile, the disadvantage of it is much metal content harmful to the environment. The natural colorant is colorant (pigment) derived from plant, animal or mineral sources. The advantage of natural dyes is that it is more environment-friendly because it is not poisonous and safe for health. The disadvantage of it is storage difficulty. When natural dyes in liquid form is stored too long, it will be decomposed easily. For that reason, it should be stored in powder form.

The method used to get natural dyes was extraction with a batch manner. The extraction was carried out with basic material-to-solvent ratios of 1:10, 1:7, and 1:5. The basic materials used were mangrove spesies rhizopora stylosa, Soga Tingi, and Indigofera. The best extract was obtained with a ratio of 1:5 for all basic materials. The powder was prepared by feeding the extracting solvent into a spray dryer so that the natural colorant powder was obtained. The application of colorant powder was used at $1 \mathrm{gram} / 100 \mathrm{ml}, 2 \mathrm{gram} / 100 \mathrm{ml}, 2 \mathrm{gram} / 100 \mathrm{ml}, 4 \mathrm{gram} / 100 \mathrm{ml}$, and 5 gram $/ 100 \mathrm{ml}$. The immersing with natural colorant was conducted in 2 conditions: extract and powder are immersing were carried out 5 times with each submerging of 15 minutes and dried. Then, fixation (color-locking) was done to batik. The fixer employed was tunjung (changing the color of batik into the darker one), alum (maintaining the batik's color), and lime (change batik color into the brighter one). The fixated batik cloth was then examined for its fading against washing using launder meter and against rubbing using crock meter. The result of the examination was analyzed using a staining scale and greyscale. The examination using the staining scale was divided into 2: wet and dry rubbings. From the result of the wet and dry rubbing test, it was obtained the best result with tingi colorant, alum fixer solution, and powder condition. Meanwhile, on the greyscale, it was obtained the best result with tingi colorant, alum fixer, and powder condition. So, it could be concluded that the optimum application of powder to batik cloth was $4 \mathrm{gram} / 100 \mathrm{ml}$ water and 5 times immersing. The best result of fading resistance against washing and rubbing was tingi with alum fixer and in powder condition.
\end{abstract}

Keywords - extraction, spray dryer, fixation, launderometer, and crockmeter

\section{Introduction}

Based on the source, textile dyes can be divided into two kinds of natural dyes and synthetic dyes (Wewa et al., 2015). Synthetic dyes are used in textile industries for dyeing nylon, wool, silk, leather and cotton. contain heavy metals that are toxic and carcinogenic so it is very dangerous for the environment (Sinha et al., 2012). Although natural dyes are safer and environmentally friendly, people prefer to use synthetic dyes because it is cheaper, can be produced in large quantities, fastness, color varies, and is available in a powder form that is more practical(Sinha, Saha et al., 2012). Unlike synthetic dyes, the natural dyes are usually renewable, being agro-renewable/vegetable based and at the same time biodegradable (Kř́žová, 2015).

Batik is one of Indonesian handicrafts produced by creating motifs on the fabric using wax and then dyed and the wax removed (Nasional, 2014). Currently, batik dyeing with 
natural dyes has been replaced by synthetic dyes for dyeing with natural dyes that take a long time and the resulting slight color variations making it less attractive. However, some manufacturers of batik while maintaining the use of natural dyes because it can produce a distinctive color, ethnicity, and not owned by synthetic dyes (CAHYANI and NOVIDAYASA, 2016).

Indonesia has a wide range of biodiversity in the form of plants that can be used as a natural textile dye maker. One of them can be used batik makers are leather mangrove spesies rhizopora stylosa, Soga Tingi, and Indigofera, Mangrove contains tannins and flavonoids.(Handayani and Maulana, 2014) Tannins and flavonoids give brown color gives a yellow color(Pujilestari, 2017). Tingi soga bark contains flavonoids and quinones. Quinone gives a yellow color to black. Cleaner soga bark contains tannin.

With the potential of Indonesia's natural resources is abundant, the exploration of the sources of natural dyes needs to be done to obtain natural dyes are more varied and lifted back the use of natural dyes for dyeing batik.

Natural dyes are now used in a liquid form then do innovation in the form of powder. Tools used to produce powder spray dryer.

\section{Materials and Methods \\ 2.1 Materials}

The feedstocks used for these experiments were a) Tingi bark and Indigofera were obtained from Solo Baru store. b) Mangrove obtained from the Kutawaru, Cilacap, Jawa Tengah. c) Water is obtained from the Laboratory of Chemical Engineering Applications, Sebelas Maret University) Primisima cloth that has been mordanted and given motif with batik wax, obtained from Batik Factory Sido Mulyo, Surakarta. e) TRO (Turkish Red Oil), alum, and tunjung are obtained from the main store, Klewer, Surakarta.

\subsection{Method}

In this experiment, the method used is a batch of dye extraction by boiling the mangrove spesies rhizopora stylosa, Soga Tingi, and Indigofera Cleaner with solvent water while stirring. On the extraction of the bark is used dry water content is low to increase the difference in the concentration of water in the material and the solvent so as to obtain a greater yield.

\section{Results and discussion \\ 3.1 Dyeing extracts}

Variation of the concentration ratio of raw material and solvent is 1:10, 1:7, and 1:5. At $1: 10$ comparative results obtained liquid extract and concentrated, with the following results:

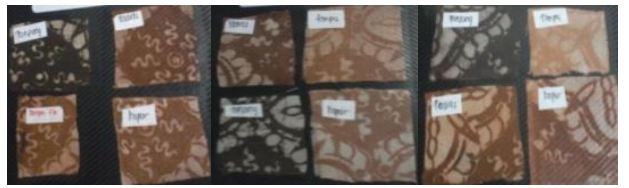

Figure 1. Results Extract Solvent Dyes, Mangrove, Tingi and Indigofera with 1:10 ratio (Sequentially from Left to Right)

On the material and solvent concentration variation in the ratio $1: 7$, the results obtained extracts and concentrated, with the following results:

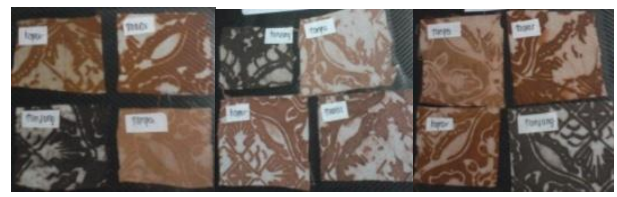

Figure 2. Results Solution dyeing extracts Mangrove, Tingi, and Indigofera with a 1:7 ratio (Sequentially from Left to Right).

At the 1:5 ratio results obtained extracts and concentrated, with the following results:

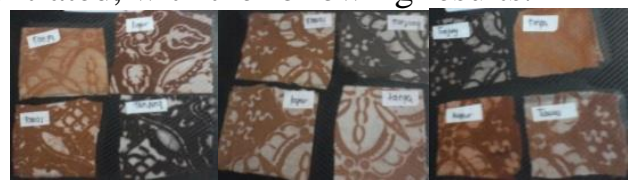

Figure 3. Results Extract Solvent Dyes, Mangrove, Tingi and Indigofera with a 1:5 ratio (Sequentially from Left to Right)

\subsection{Drying Dyes}

In this experiment, batch extraction is done with a volume of $2500 \mathrm{ml}$ of solvent within 2 hours for 500 grams of Mangrove spesies rhizopora stylosa, Tingi, and Indigofera. Then the solution is evaporated to extract its volume to $1000 \mathrm{ml}$ and dried with a spray dryer to produce natural dye powder.

\subsection{Staning Batik}

\section{a. Concentration Variation Dyes}

In this experiment, the dye powder dissolved in $100 \mathrm{ml}$ of water with a variety of powder weighing 1 gram, 2 grams, 3 grams, 4 grams, and 5 grams. Then the cloth is already 
mordanted and given a wax batik motif with a cut to the size of $10 \mathrm{~cm} \mathrm{x} 10 \mathrm{~cm}$ by 5 strands. Each cloth soaked in the dye solution with different concentrations for $15 \mathrm{~min}$ and then dried.

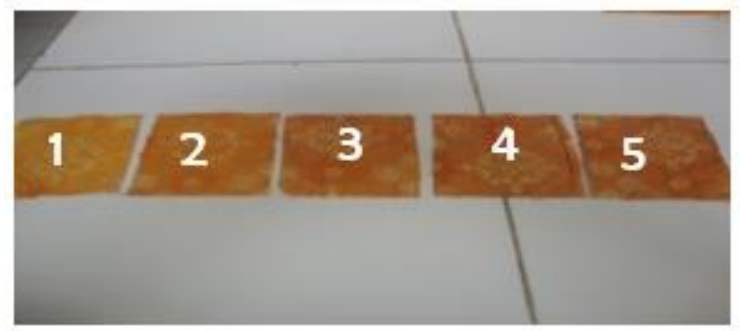

Figure 4. Results immersion with 1, 2, 3, 4, 5 grams of substance in $100 \mathrm{ml}$ Water Colors (Sequentially from Left to Right)

Based on the experimental results, the higher the concentration of the dye solution resulting color on faded cloth (old) because the dyes are absorbed more and more. However, at a concentration of $4 \mathrm{~g}$ in $100 \mathrm{ml}$ and 5 grams in $100 \mathrm{ml}$ produced the same color as the concentration of $4 \mathrm{~g}$ in $100 \mathrm{ml}$ of the dye has a maximum absorption so that the fibers can no longer absorb the dye.

\section{b. Variation Total Immersion}

Cloth that has been given a motif, mordanted, and cut to a size of $10 \mathrm{~cm} \times 10 \mathrm{~cm}$ by 6 pieces, then each piece is dipped in dye solution with a concentration of $4 \mathrm{ml}$ gram/100 dyeing variations as much as 1 times, 2 times, 3 times , 4 times, 5 times, and 6 times, which is performed every 1 time immersion for 15 minutes then drained and newly dyed again. The fabric is dried in the shade so the color does not fade. Dyeing results as follows:
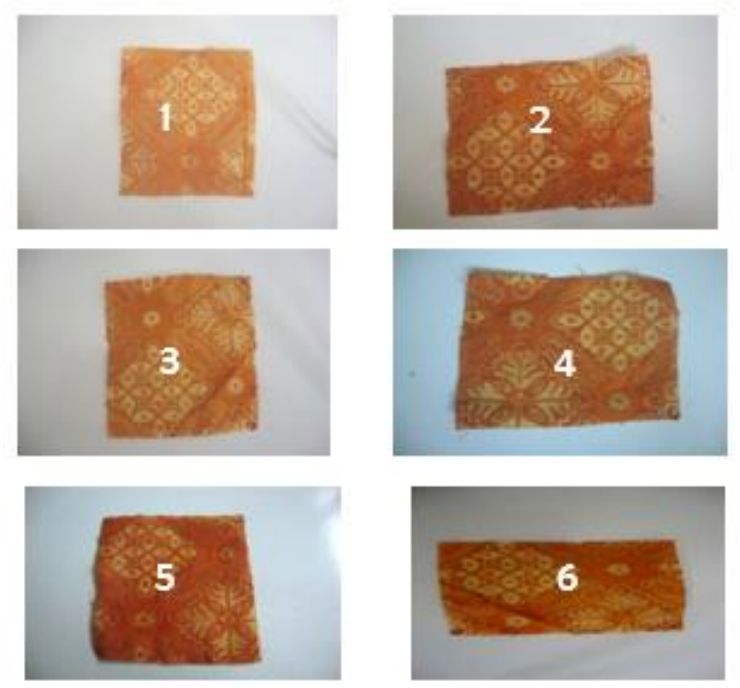

Figure 5. Immersion 1, 2, 3, 4, 5, and 6 times

\section{c. Variations Solution Fixer}

In this experiment, the fabric has been given a motif and cut to a size of $10 \mathrm{~cm} \mathrm{x} 10$ $\mathrm{cm}$ by 4 pieces, then dipped in a dye solution concentration of $4 \mathrm{ml}$ gram/100 5 times) which is 1 times the dyeing is done for 15 minutes, followed by drying, and newly dyed again. Then fixed with cloth fixer solution is different lotus or $\mathrm{FeSO}_{4}$ solution, lime, alum, and one piece of cloth is not fixed and used as a comparison. Fixation results as follows:
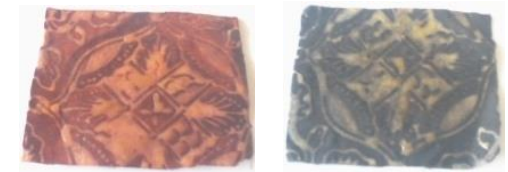

Figure 6. Tunjung Figure 7. Lime
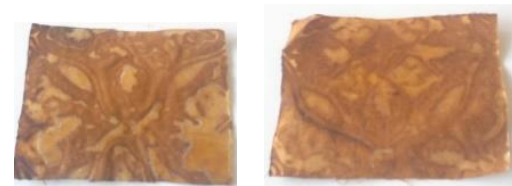

Figure 8. TawasFigure 9. Without Fixation

From the figure above it can be seen that the fixation with a solution lotus effect older, younger limestone effect, and alum gives a moderate effect on the color (as the original color).

\subsection{Removal of Wax}

Candles attached to the cloth is removed by boiling the cloth in boiling water while It rubbed. At the temperature of the dye is only slightly soluble in water. Wax removal results can be seen in the following figure.

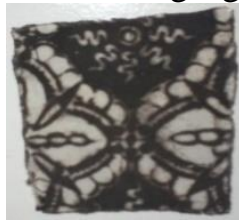

Figure 10. Results Removal Wax on Cloth with Tunjung Fixer

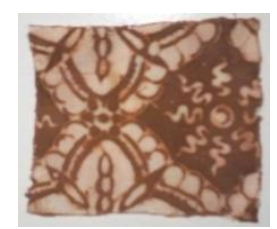

Figure 11. Results Removal Wax on Cloth with Tawas Fixer 


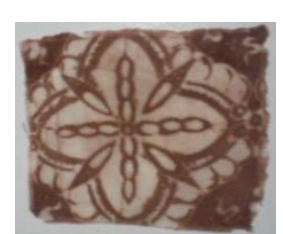

Figure 12. Results Removal Wax on Cloth with Lime Fixer

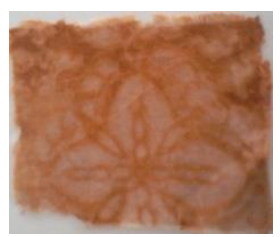

Figure 13. Results Removal Wax on Cloth Without Fixation

Part of the fabric removed white candle (corresponding primary color fabrics) because at the time of immersion dye cannot penetrate the wax layer. While the fabric will not be given a colored wax according to the dyes used and fixer solution.

\subsection{Endurance Test Fade}

Results batik dyeing with natural dyes from mahogany skin, jambal bark, and bark were further tested steeper erosion resistance to rubbing with dry and wet rubbing fastness crock meter and laundry with launderometer. The test results were analyzed by staining the crock meter scale and the test results were analyzed by staining launderometer scale and grayscale. 
Table 1. Rubbing Wet Test Results with Scale Staining

\begin{tabular}{|c|c|c|c|c|c|c|c|c|}
\hline \multirow{2}{*}{$\begin{array}{l}\text { Type of } \\
\text { material }\end{array}$} & \multicolumn{4}{|c|}{ Extract } & \multicolumn{4}{|c|}{ Powder } \\
\hline & Tawas & Tunjung & Kapur & Tanpa & Tawas & Tunjung & Kapur & Tanpa \\
\hline Tingi & Good & Good & Good & $\begin{array}{c}\text { Good } \\
\text { enough }\end{array}$ & Excellent & Good & Good & Good enough \\
\hline Jambal & Excellent & Good & Good & Good & Excellent & Good & Excellent & Good \\
\hline Mahoni & Excellent & Good & Good & Good & Excellent & Good & Good & Good \\
\hline
\end{tabular}

Table 2. Test Results with Dry rub Staining Scale

\begin{tabular}{|c|c|c|c|c|c|c|c|c|}
\hline \multirow{2}{*}{$\begin{array}{c}\text { Type of } \\
\text { material }\end{array}$} & \multicolumn{4}{|c|}{ Extract } & \multicolumn{4}{c|}{ Powder } \\
\cline { 2 - 9 } & Tawas & Tunjung & Kapur & Tanpa & Tawas & Tunjung & Kapur & Tanpa \\
\hline Tingi & Excellent & Good & Good & Good & Excellent & Good & Excellent \\
\hline Mahbal & Excellent & Good & Good & Good & Excellent & Excellent & Excellent & Good \\
\hline
\end{tabular}

Table 3. Test Results discoloration on staining of laundry with Scale

\begin{tabular}{|c|c|c|c|c|c|c|c|c|}
\hline \multirow{2}{*}{$\begin{array}{c}\text { Type of } \\
\text { material }\end{array}$} & \multicolumn{4}{|c|}{ Extract } & \multicolumn{4}{c|}{ Powder } \\
\cline { 2 - 8 } & Tawas & Tunjung & Kapur & Tanpa & Tawas & Tunjung & Kapur & Tanpa \\
\hline Jingi & Good & Good & Good & $\begin{array}{c}\text { Good } \\
\text { enough }\end{array}$ & Good & Good & Good \\
\hline Mahoni & Excellent & Good & Good & Good & Excellent & Excellent & Excellent & Good \\
\hline
\end{tabular}

Table 4. Discoloration Test Results with Grey Scale

\begin{tabular}{|c|c|c|c|c|c|c|c|c|}
\hline \multirow{2}{*}{$\begin{array}{c}\text { Type of } \\
\text { material }\end{array}$} & \multicolumn{4}{|c|}{ Extract } & \multicolumn{4}{|c|}{ Powder } \\
\hline & Tawas & Tunjung & Kapur & Tanpa & Tawas & Tunjung & Kapur & Tanpa \\
\hline Tingi & Good & Good & Good & $\begin{array}{l}\text { Good } \\
\text { enough }\end{array}$ & Good & Good & Good & Good enough \\
\hline Jambal & Good & $\begin{array}{l}\text { Good } \\
\text { enough }\end{array}$ & Good & $\begin{array}{l}\text { Good } \\
\text { enough }\end{array}$ & Good & Good & Good & Good \\
\hline Mahoni & Good & $\begin{array}{l}\text { Good } \\
\text { enough }\end{array}$ & Good & $\begin{array}{l}\text { Good } \\
\text { enough }\end{array}$ & Good & $\begin{array}{l}\text { Good } \\
\text { enough }\end{array}$ & Good & Good enough \\
\hline
\end{tabular}


According to Tables 1 and 2, between the four conditions above fabrics, fastness to rubbing dry most well demonstrated by batik cloth is fixed with alum. Dry rub than to test extracts and powders obtained fastness quality beneath row indicated by fabric fixed with lime, lotus, and the worst is the fabric without fixation. Fastness results it is best to tingi soga bark. Then to test the results of batik cloth with rubbing wet conditions and dry rub obtained the best results by using a dry rub.

According to the table 3 . fastness to washing with staining scale and table 4. fastness against washing with grayscale is best exemplified by batik cloth is fixed with alum. Later for extracts and powders obtained fastness quality beneath row indicated by fabric fixed with lime, lotus, and the worst is the fabric without fixation. Fastness results it is best to tingi soga bark. Based on tables 1, 2, 3, and 4 in faded conditions and resistance against rubbing color are best with powder.

\section{Conclusions.}

Based on the experimental results obtained as follows: Optimum application of powder to the batik fabric is 4 grams of powder in $100 \mathrm{ml}$ of water with 5 times the dyeing and the fixer 14 grams of alum in $100 \mathrm{ml}$ of water. The best result of natural dyes in batik cloth to wash and rub fastness are tingi soga bark with alum fixer solution and in powder conditions.

\section{Acknowledgments}

The research team would like to thank the Director-General of Research and Education and LPPM UNS for providing funding through the PTUPT research scheme with the contract No.: 208/SP2H/LT/DRPM/2019 as well as UMKM Soul Craf and Sanggar Batik Canting.

\section{References}

Cahyani, M. D. and Novidayasa, I.2016, Ekstraksi Zat Warna Alami dari Kayu Bakau (Rhizophora Mucronata) dengan Metode Microwave Assisted Extraction, Institut Teknologi Sepuluh Nopember.

Handayani, P. A. and Maulana, I., 2014, Pewarna alami batik dari kulit soga tingi (Ceriops tagal) dengan metode ekstraksi, Jurnal Bahan Alam Terbarukan, 2,(2).

Krrížová, H., 2015, Natural dyes: their past, present, future and sustainability, Technical University of Liberec, 461, 17.
Nasional, B. S.2014, Batik, Pengertian dan Istilah.

Pujilestari, T., 2017, Optimasi Pencelupan Kain Batik Katun Dengan Pewarna Alam Tingi (Ceriops Tagal) Dan Indigofera SP, Dinamika Kerajinan dan Batik, 34,(1), 5362.

Sinha, K., Saha, P. D. and Datta, S., 2012, Extraction of natural dye from petals of Flame of forest (Butea monosperma) flower: Process optimization using response surface methodology (RSM), Dyes and Pigments, 94,(2), 212-216.

Wewa, S., Saengpaen, P., Rodbangpong, K. and Khucharoenphaisan, K., 2015, Optimization of Dyed Extract Condition from Nypa Palm Bark using Central Composite Design, Asian Journal of Agricultural Research, 9,(6), 362-366. 